\title{
Concentrate on fundamentals
}

"WE are here today", said Mr Ian Lloyd as he opened the Science Sub-Committee hearings on the needs of scientific research in British Universities, "to look into the funding of scientific research from all sources, public and private. The University Grants Committee, the Research Councils, charities and foundations - we shall investigate the distribution of funding amongst them. We shall also look at the relation of research to teaching, and the implication of changes in funding on research." To hear the six witnesses, there were three MPs, four pressmen and one member of the general public. Hardly an auspicious beginning to a penetrating survey.

On display were representatives from two of the newer and more technologically-oriented universities-City and Brunel. It was difficult to discern any very clear threads from their presentations. There was a certain amount of special pleading for things like tenured technicians, more travel money and less accounting duties, but the array of professors lost a major opportunity to put sharply in focus the plight of universities. Instead they indulged in a rambling dialogue in which important points were left unmentioned or given inadequate emphasis. Out of it all emerged a picture of two universities whose professors have slight chips on their shoulders about status and have a general desire to do something about the Science Research Council, but no very clear idea what they would do.

The most worrying impression left was that whilst the educational system faced crisis and some departments are denuded of students, there is no serious thought given to a strategy for universities or any well markedout policy options which are being discussed in commonrooms. If universities themselves cannot present compelling evidence that they are thinking carefully about policy, they must expect that policy will be decided for them.

The primary need of scientific research is a continuous flow of highly intelligent manpower, and it is to this problem that the committee should pay greatest attention, for if the numbers coming into science at the undergraduate level continue to decline, then the raison d'etre for many university staff disappears and any call for new facilities and equipment or even for the long-term financial commitments that every Vice-Chancellor dreams of landing is bound to be muted. Unfortunately, few in the university environment have yet come up with much original thinking either on how to reverse the decline or what to do if the decline proves irreversible. There are, of course, various crumbs of comfort; up to the present the loss in recruitment has been mainly of the less qualified, and up to the present it has been possible to fill classes up with overseas students. But both of these situations could change within a year or two for the worse.

Although a City representative did touch on the "disastrous shortfall" in native-born applicants for graduate studentships, he did not pursue any line of thought on reasons why or remedies considered-nor, one suspects, will many of those who come to give evidence. It is unthinkable that a business which saw a steady decline in demand for its services would not go to great lengths to learn about the trend and try to respond to it; the committee would do well to ask some plain questions of future witnesses on their understanding of the decline in recruitment to science-maybe to the extent of asking whether the trend towards producing 44 equal universities (and even moving the polytechnics up to a level footing) is an intelligent response to a situation in which the science departments of half these universities are gasping for students.

Future witnesses might also be at some pains to spell out their views on the purpose of a university. Not unnaturally, in times like these the committee is pursuing rather doggedly the question of science in the national interest and the need for better industry/university links. Science for the country is a particularly tricky issue and needs some careful prior thought. If the laboratories really are full of overseas students, and if the international corporation, capable of exporting technology at will, increasingly dominates science-based industry, then talk of national interest is bound to become of diminishing relevance.

Certainly the international context of science-even the European dimension--is a difficult idea to get through to politicians who obviously want to see returns for taxpayers' money. And yet to fail to make the broader scene clear would be to run the risk that university science departments be forced to pay too much attention to presumed national needs-and too little to the advancement of learning. 